УДК : 338.43

\title{
ДЕРЖАВНА ПІДТРИМКА АГРАРНОГО СЕКТОРУ \\ В УМОВАХ МІЖНАРОДНОЇ КООРДИНАЦІЇ \\ ЕКОНОМІЧНОЇ ПОЛІТИКИ 1995-2012 pp.: ЗАРУБІЖНИЙ ДОСВІД
}

\section{Ревенко Анатолій Дмитрович}

Надіслано:

27.12.2019

Рецензовано:

15.01.2020

кандидат економічних наук, доцент, Прийнято:

Київський університет культури,

21.01.2020

м. Київ, Україна

ORCID: 0000-0002-4555-0677

revenkoad@ukr.net

У статті проаналізовано механізм реалізації державної аграрної політики у прогресуючих на період 1995-2012 рр. країнах, таких як Китай, Бразилія, Індія та ПАР в умовах багатостороннього регулювання світових сільсько-господарських ринків, що дозволило виявити специфіку кожної й найбільш поширені способи адаптації державної підтримки сільського господарства до національних зобов'язань перед СОТ. Розглянуто загальні напрямки коригування державної аграрної політики згаданих країн: збереження, в головному, рівня тарифного, а десь й нетарифного захисту з послідовним переведенням останнього на єдині стандарти; поступовий перехід до найменш деструктивних відносно ринку форм підтримки агровиробників; підтягування до середніх питомих показниками рівнів PSE i TSE у країнах ОЕСР. Вступ до СОТ і прийняття фіксованих зобов'язань не сповільнили розвиток аграрного сектора зазначених країн, що підтверджується, по-перше, динамікою валового сільськогосподарського виробництва, яка різко прискорилася якраз на етапі 2000-х рр. й випередила темпи зростання населення; по-друге, зростанням рівня продуктивності сільського господарства. Доведено, що членство у СОТ не перешкоджає пошуку індивідуальних, «заточених» під конкретику певного періоду в окремій країні форм підтримки сільського господарства, логічно стимулюючи їхне наближення спочатку до рівня бажаних прямих платежів, що підвищують доходи фермерів, а згодом - до зеленої корзини, залишаючи простір для «виторговування» сприятливих умов державної підтримки розвитку сільського господарства в рамках Дохійського раунду переговорів.

Ключові слова: державна аграрна політика; країни, що розвиваються; Китай;Бразилія; Індія;ПАР; міжнародна координація економічної політики. 
Revenko Anatolii, Candidate of Economic Sciences, Associate Professor, Kyiv University of Culture, Kyiv, Ukraine

State Agrarian Sector Support in the Conditions of the 1925-2012 Economic Policy International Coordination:

\section{Foreign Experience}

The article analyzes the mechanism of implementation of the state agrarian policy in progressing for the period 1995-2012. In countries such as China, Brazil, India and South Africa, in the context of multilateral regulation of world agricultural economic markets, it was possible to identify the specifics of each and the most common ways of adapting state support for agriculture to national obligations to the WTO. The general directions of adjusting the state agrarian policy of the mentioned countries are considered: preservation, basically, on the level of tariff, and somewhere non-tariff protection, with the subsequent transfer of the latter to uniform standards; gradual transition to the least destructive in relation to the market forms of support for agricultural producers; pulling average PSE and TSE levels in OECD countries to average specific indicators. Accession to the WTO and the adoption of fixed obligations did not slow down the development of the agricultural sector of these countries, which is confirmed, firstly, by the dynamics of gross agricultural production, which accelerated sharply at the stage of the 2000s and outpaced the population growth rate; secondly, an increase in agricultural productivity. It is proved that membership in the WTO does not prevent the search for individual forms of support for agriculture that are tailored to the specifics of a certain period in a particular country, logically stimulating their approach first to the level of desired direct payments, increasing the income of farmers, and then in the green basket, leaving space to "bargain" for favourable conditions for state support for agricultural development within the framework of the Doha round of negotiations.

Key words: state agrarian policy; developing countries; China, Brazil, India, South Africa; international coordination of the economic policy.

Ревенко Анатолий Дмитриевич, кандидат экономических наук, доцент, Киевский университет культуры, г. Киев, Украина

Государственная поддержка аграрного сектора в условиях международной координации экономической политики 1995-2012 гг.: зарубежный опыт

В статье проанализирован механизм реализации государственной аграрной политики в прогрессирующих на период 1995-2012 гг. странах, таких как Китай, Бразилия, Индия и ЮАР в условиях многостороннего регулирования мировых сельскохозяйственных хозяйственных рынков, что позволило выявить специфику каждой страны и наиболее распространенные способы 
адаптации государственной поддержки сельского хозяйства к национальным обязательствам перед ВТО. Рассмотрены общие направления корректировки государственной аграрной политики упомянутых стран: сохранение, в основном, уровня тарифной, а где-то и нетарифной защиты с последовательным переводом последней на единые стандарты; постепенный переход к наименее деструктивным формам поддержки агропроизводителей относительно рынка; подтягивание к средним удельным показателям уровней PSE и TSE в странах ОЭСР. Вступление в ВТО и принятия фиксированных обязательств не замедлили развитие аграрного сектора указанных стран, что подтверждается, во-первых, динамикой валового сельскохозяйственного производства, которая резко ускорилась на этапе 2000-х гг. и опередила темпы роста населения; во-вторых, ростом уровня производительности сельского хозяйства. Доказано, что членство в ВТО не препятствует поиску индивидуальных, «заточенных» под конкретику определенного периода в отдельной стране, форм поддержки сельского хозяйства, логично стимулируя их приближение сначала до уровня желаемых прямых платежей, повышающих доходы фермеров, а затем - к зеленой корзине, оставляя пространство для «выторговывания» благоприятных условий государственной поддержки развития сельского хозяйства в рамках Дохийского раунда переговоров.

Ключевые слова: государственная аграрная политика; развивающиеся страны; Китай; Бразилия; Индия; ЮАР; международная координация экономической политики.

\section{Вступ}

Як підтверджує світова практика, розвиток сільського господарства від моменту становлення державності завжди опирався на відповідну державну аграрну політику (далі у тексті - ДАП), що еволюціонувала у декілька етапів. Ії̈ основу становили питання регулювання земельних відносин, забезпечення продовольчої безпеки й налагодження стабільного постачання сільськогосподарської сировини до переробних виробництв. Незважаючи на те, що історики вказують на більш ніж 2000-літній досвід розвитку аграрної політики, проте сучасні експерти та дослідники сходяться на думці, що переважна більшість заходів у цьому напрямку впродовж тривалого періоду вирізнялися превентивним характером, натомість активна фаза розпочалася з початком промислової революції у Європі, яка була своєрідним поштовхом до побудови системи державного регулювання й підтримки сільського господарства та переробних виробництв. В межах цієї активної фази виокремлюють три етапи: 1) зародження ДАП (поч.XIX-1920-ті рр.); 2) формування системи державного регулювання сільського господарства 
Міжнародні відносини: теоретико-практичні аспекти

Випуск 5 (2020)

ISSN (print) 2616-745X; ISSN (online) 2616-7794

(1930-1980-ті рр.); 3) становлення моделі ДАП на засадах концепції сталого розвитку (1980-ті рр. - сьогодення).

Звертаючи увагу на останній етап, який характеризується відновленням екологічної рівноваги на основі науково-технічного прогресу й комплексним освоєнням потенціалу сільськогосподарських територій, варто відмітити, що успішні практичні напрацювання США й низки європейських країн (Франція, Нідерланди, Німеччина, Великобританія) зумовили сталий розвиток всього комплексу відповідних галузей та сприяли їх утвердженню на лідуючих позиціях у світовому агропродовольчому секторі. Приміром, з часів Другої світової війни Америка є лідером рейтингу світових «сільськогосподарських» держав і найбільших експортерів, а також впродовж останніх 50 років стабільно входить до 5 провідних агроекспортерів. Стосовно Європейського Союзу, то станом на 2012 р. він є провідним експортером сільгосппродукції (37 \% проти 10,4 \% у США).

Разом з тим, на сучасному етапі стабільне функціонування світових продовольчих ринків істотно зумовлюється ефективністю налагодження механізмів інтеграції аграрного сектора економіки країн, що розвиваються, до міжнародної системи поділу праці, особливо, коли йдеться про Китай, Індію чи Бразилію. Також важливо розглянути цю проблему в світлі виконання зобов'язань, зафіксованих під час приєднання до Світової організації торгівлі (далі у тексті - СОТ) Китаю, а також відповідних зобов'язань, закріплених в ході Уругвайського раунду переговорів для Бразилії, Індії та Південно-Африканської Республіки (ПАР).

Якщо застосувати порівняльний аналіз до найважливіших підсумків практичної реалізації досягнутих домовленостей, які намітилися до початку 2010-х рр., то тоді можна спробувати виявити найбільш дієві інструменти ДАП країн, що розвиваються на етапі глобалізації світової економіки. Зрозуміло, що універсальних рецептів не існує, однак, спроба «знахідок і помилок» стосовно вивчення зарубіжного досвіду може стати у нагоді під час формулювання пропозицій щодо можливого коригування ДАП України в межах прийнятих зобов'язань перед СОТ.

Відповідно до Угоди про сільське господарство 1994 р. усі прийняті країнами «аграрні» зобов'язання в ході вступу до СОТ передбачають, по-перше, доступ до внутрішнього ринку, по-друге, підтримку національних виробників, й, по-третє, можливі параметри експортного субсидування. Обсяг й характер зобов'язань, прийнятих під час вступу до СОТ, вирішальним чином залежить від самостійно обраного статусу між розвиненими країнами й тими, що розвиваються. Деякі члени Організації економічного співробітництва та розвитку (ОЕСР), зокрема Ізраїль, Мексика, Туреччина, Чилі, Республіка Корея обрали останній, тоді як ПАР вважає за краще членство «вищого розряду». Крім 
того, параметри державної підтримки АПК, котра підлягає скороченню, залежать від конкретного внеску з боку окремої країни до бази (FBTAMS), що, наприклад, для Індії й Китаю суттєво звузило простір для бюджетного маневру.

\section{Аналіз останніх досліджень і публікацій}

Розглядаючи ДАП в умовах міжнародної координації економічної політики в окреслений час на прикладі передових й прогресуючих країн, потрібно звернутися до збірників «Аграрна політика у країнах, що розвиваються 2009: Моніторинг та оцінка» (Agricultural Policies in Emerging Economies, 2009), «Моніторинг та оцінка аграрної політики 2011: країни ОЕСР та країни, що розвиваються» (Agricultural Policy Monitoring and Evaluation, 2011), «Моніторинг та оцінка сільськогосподарської політики 2012: країни ОЕСР» (Agricultural Policies Monitoring and Evaluation, 2012), «Моніторинг та оцінка аграрної політики 2013: країни ОЕСР та країни, що розвиваються» (Agricultural Policy Monitoring and Evaluation, 2013), «Питання сільського господарства, торгівлі й продовольчої безпеки та варіанти переговорів СОТ з позиції країн, що розвиваються» (Agriculture, Trade and Food Security, 2000) та ін. Окремим, але не менш важливим блоком йдуть статистичні дані (OECD Statistics; WTO Statistics Database; World Bank Indicators). Також необхідно відзначити роботи Л. Брінка, Д. Ордена та Г. Даца (Brink, Orden, Datz, 2013), С. Грінберга (Greenberg, 2010), Б. Дхара (Dhar, 2004), Дж. Гуанга й С. Розель (Huang, Rozelle, 2002) та ін.

\section{Формулювання мети і завдань статті}

Головна мета статті - розкрити особливості державної підтримки аграрного сектору в умовах міжнародної координації економічної політики у період 1995-2012 рр. на прикладі країн розвинених і тих, що стрімко розвиваються. Задля цього відштовхнемось від 1995 р. (час заснування СОТ) або зваженого підсумку за триріччя 1995-1997 рр., натомість порівняльною точкою виступатиме останній рік, за який відомі порівняльні дані ОЕСР. У цьому ключі спочатку потрібно виявити зміну ролі сільського господарства в економіці обраних країн за вказаний період, потім оцінити структурну рекомпозицію ДАП у ключі вимог СОТ, а головну увагу зосередити на аналізові й характеристиці еволюції базових інструментів ДАП, виокремивши два рівні внутрішню підтримку сільськогосподарських виробників й зовнішньоторговельне регулювання відповідних ринків.

\section{Виклад основного матеріалу дослідження}

Необхідно почати 3 висвітлення базових зобов'язань прогресуючих країн стосовно корегування ДАП під час вступу до COT (Agricultural Policy in South Africa; Agriculture, Trade and Food Security, 2000; Dhar, 2004). Для прикладу, візьмемо чотири країни, - Бразилію, Індію, ПАР й Китай, - 
порівнявши їхні показники за трьома критеріями: доступ на внутрішній ринок, підтримка агровиробників й експортні субсидії. Отже:

1. Бразилія. Ставка пов'язаного тарифу - 35,4\% (у 2012 р. фактична ставка - 10,1\%). Тарифні квоти залишені на 2 види продукції - зернові та фрукти. Разом з Індією й Китаєм вступала до СОТ як країна, що розвивається. Підтримка агровиробників за «протоколом» AMS/ FBTAMS - 912,1 млн дол. Експортні субсидії на 16 видів продукції за умови скорочення на $24 \%$ до базового періоду до 73 млн дол. у 2004 р.

2. Індія. Ставка пов'язаного тарифу - 113,1\% (у 2012 р. фактична ставка - 33,5 \%). Тарифні квоти залишені на 4 види продукції: кукурудзу, сухе молоко, рапсове або гірчичне масло, соняшникову олію. Підтримка агровиробників за «протоколом» AMS/ FBTAMS - 0. Скасовані усі кількісні обмеження сільськогосподарського імпорту до квітня 2001 р. Зобов'язань щодо кількісних обмежень (з огляду на незастосування) не передбачено.

3. Південно-Африканська Республіка. Ставка пов'язаного тарифу 39,6 \% (у 2012 р фактична ставка - 8,4 \%). Тарифні квоти залишені на 26 видів продукції із внутрішньоквотною ставкою не більше 20 \% відповідної пов'язаної ставки тарифу. Підтримка агровиробників за «протоколом» AMS/ FBTAMS 2,0 млрд рандів. Експортні субсидії підлягають скороченню на 36\% до 570 млн. рандів до 2000 р.

4. Китай. Ставка пов'язаного тарифу - 15,7\% (у 2011 р. фактична ставка - 15,6\%). Залишені тарифні квоти на 7 видів продукції: рис, пшениця, кукурудза, бавовна, шерсть, харчові рослинні олії, цукор. Практично обнуляються мита на ввезення промислової продукції для сільського господарства. Підтримка агровиробників на рівні 0. Експортні субсидії - повне скасування й заборона на використання у майбутньому.

3 огляду на характеристику сучасного перепозиціонування сучасного сільського господарства країн, що розвиваються, виділимо, по-перше, послідовне зниження частки аграрного сектора у формуванні ВВП й підтримці загальної зайнятості. По-друге, враховуючи інтегрування прогресуючих країн до світових ринків сільськогосподарської сировини й продовольства, не можна не звернути увагу на дві полярні тенденції: масовому зниженню частки сільського господарства у сумарному імпорті протистоїть в цілому збереження або навіть нарощування частки аграрного сектору в сумарному експорті (наприклад, до $35,6 \%$ у Бразилії), що супроводжується збільшенням позитивного сальдо агропродовольчого експортно-імпортного балансу (до феноменальних 72,6 млрддол. у Бразилії) за винятком Китаю (мінус 90,1 млрд дол. у 2012 р.) й ПАР (мінус 0,8 млрд дол. у 2012 р.). По-третє, виходячи зі співвідношення скромного внеску сільського господарства у ВВП й істотної сільської зайнятості у рамках загально підсумкової, можна побічно 
судити про невисокий рівень продуктивності праці у аграрній сфері: приміром, у Китаї іï рівень станом на кінець 2000-хрр. становив 1/5 від загальнонаціонального рівня.

Опираючись на статистичний аналіз, наведемо дані, що підтверджують зміну ролі сільського господарства у межах економіки прогресуючих країн:

Таблиця 1

\begin{tabular}{|c|c|c|c|c|c|c|c|c|}
\hline \multirow{2}{*}{ Показник } & \multicolumn{2}{|c|}{ Бразилія } & \multicolumn{2}{|c|}{ Індія } & \multicolumn{2}{|c|}{ Китай } & \multicolumn{2}{|c|}{ ПАР } \\
\hline & 1995 & 2012 & 1995 & 2012 & 1995 & 2012 & 1995 & 2012 \\
\hline $\begin{array}{c}\text { Валове } \\
\text { сільськогоспо- } \\
\text { дарське } \\
\text { виробництво, } \\
\text { млрд дол. } \\
\end{array}$ & 58,2 & $199,2^{*}$ & 99,7 & $265,5^{*}$ & 270,2 & $1102,4^{*}$ & 9,2 & $22,2^{*}$ \\
\hline $\begin{array}{c}\text { Частка } \\
\text { сільського } \\
\text { господарства } \\
\text { у ВВП, \% }\end{array}$ & 5,8 & 5,2 & 26,3 & 17,4 & 20,2 & $10^{*}$ & 3,9 & 2,6 \\
\hline $\begin{array}{c}\text { Частка } \\
\text { сільського } \\
\text { господарства } \\
\text { у загальній } \\
\text { зайнятості, \% }\end{array}$ & 26,1 & $17^{*}$ & 61 & $51^{*}$ & 52,2 & $39,6^{*}$ & 16 & $5,1^{*}$ \\
\hline $\begin{array}{c}\text { Частка } \\
\text { сільського } \\
\text { господарства } \\
\text { у загальному } \\
\text { експорті, \% }\end{array}$ & 29,3 & 35,6 & $19,5^{* *}$ & 14,4 & 7,7 & 3,2 & 8,0 & 9,5 \\
\hline $\begin{array}{c}\text { Частка } \\
\text { сільського } \\
\text { господарства } \\
\text { у загальному } \\
\text { імпорті, \% } \\
\end{array}$ & 12,4 & 5,9 & $7,3^{* *}$ & 5,2 & 8,2 & 8,6 & 7,3 & 7,3 \\
\hline $\begin{array}{c}\text { Агропродоволь- } \\
\text { чий експортно } \\
\text { імпортний } \\
\text { баланс, млн дол. } \\
\end{array}$ & 6976 & 72590 & 3319 & 16896 & 551 & -90824 & 292 & $-780,6$ \\
\hline $\begin{array}{c}\text { Сільськогоспо- } \\
\text { дарські } \\
\text { території, } \\
\text { млн га } \\
\end{array}$ & 258,5 & $275^{*}$ & 180,8 & $179,8^{*}$ & 532,7 & $519,1^{*}$ & 99,5 & $96,4^{*}$ \\
\hline
\end{tabular}

Примітка. * за 2011 р.; ** за 1990 p.

Серед усього загалу проблем, які стримують зростання продуктивності праці, ледь не центральне місце займає незавершеність земельної реформи, як у Китаї, де земля знаходиться у власності сільських громад, що передають їі у 30-річну оренду (без права продажу) індивідуальним господарствам тільки для використання за призначенням, або у Індії, де заснована на праві 
Міжнародні відносини: теоретико-практичні аспекти

Випуск 5 (2020)

ISSN (print) 2616-745X; ISSN (online) 2616-7794

спадкування (діти отримують частки успадкованого майна) система землекористування, доповнена законодавчими обмеженнями граничних розмірів землеволодіння (від 15 до 70 га незрошуваних земель, від 10 до 18 га меліорованих земель на 2 врожаї на рік, від 10 до 30 га зрошуваних земель на 1 врожай на рік), фактично закриває сільським жителям можливість виходу за межі сільського господарства. Вона провокує збереження значного прошарку дрібнотоварного виробництва (у Китаї середній розмір селянського господарства дорівнює 0,6 га, у Індії - 1,3 га на 2005 р.) (Agricultural Policies in Emerging Economies, 2009, p. 107).

В кінцевому підсумку все це обертається соціальними перекосами, які відбиваються, насамперед, на сільських жителях (у Китаї реальні доходи селян менше 1/3 рівня городян; у ПАР на 240 тис. товарних ферм припадає від 2 до 4 млн ферм, які ведуть виключно натуральне господарство (Federico, 2005, p. 40), а за «законом сполучених посудин» захоплює всі інші сектори економіки: якщо у Бразилії з п'ятизначним показником ВВП на душу населення $13 \%$ жителів (головним чином сільських) живуть на 2 дол. у день, то в Індії, де ВВП на душу населення вчетверо нижче, цей відсоток перевищує 80 (Federico, 2005, p. 40).

Збереження стабілізуючої функції сільського господарства у суспільстві в поєднанні $з$ переплетенням вищезазначених й неназваних тут проблем, що стримують розвиток аграрного сектора, пояснює надважливість вивіреності державної аграрної політики країн, що розвиваються. Її трансформацію за 1990-2000-ті рр. представимо за допомогою нижче наведеної таблиці, де за точку відліку взято показник оцінки підтримки агровиробників (PSE), що використовується ОЕСР (Agricultural Policies in Emerging Economies, 2009, p. 43, 79, 137, 151; Agricultural Policy Monitoring and Evaluation, 2013, p. 91, 121, $251,277)$. При цьому, важливо зосередитися на характеристиці головних складових «внутрішньої» підтримки фермерства та зовнішньо-торговельної політики на ринках сільськогосподарської сировини й продовольства в контексті обраних для порівняння країн з акцентом на виявлення специфіки етапу, початок якому поклало створення СOT. 
Таблиця 2

\begin{tabular}{|c|c|c|c|c|}
\hline Показник & Роки & Бразилія & Китай & ПАР \\
\hline \multirow{3}{*}{ PSE, \% від усіх надходжень фермерів } & $1995-1997$ & -12 & 2 & 11 \\
\hline & $2005-2007$ & 6 & 9 & 6 \\
\hline & $2010-2012$ & 5 & 15 & 3 \\
\hline \multirow{3}{*}{$\begin{array}{c}\text { Підтримка, пов'язана з товарним } \\
\text { виробництвом / support based on } \\
\text { commodity output, }\end{array}$} & 1995-1997 & 144 & 23 & 96 \\
\hline & $2005-2007$ & 40 & 31 & 77 \\
\hline & $2010-2012$ & 50 & 68 & 54 \\
\hline \multirow{3}{*}{$\begin{array}{c}\text { з них: підтримка ринкових цін / market } \\
\text { price support }\end{array}$} & $1995-1997$ & 145 & 23 & 96 \\
\hline & $2005-2007$ & 33 & 31 & 77 \\
\hline & $2010-2012$ & 48 & 68 & 54 \\
\hline \multirow{3}{*}{$\begin{array}{c}\text { підтримка нарощування обсягів } \\
\text { виробництва / payments based on output }\end{array}$} & 1995-1997 & -1 & 0 & 0 \\
\hline & $2005-2007$ & 7 & 0 & 0 \\
\hline & $2010-2012$ & 4 & 0 & 0 \\
\hline \multirow{3}{*}{$\begin{array}{l}\text { Субсидування використання вхідних } \\
\text { pecурсів / payments based on input use }\end{array}$} & 1995-1997 & -44 & 66 & 2 \\
\hline & $2005-2007$ & 59 & 41 & 19 \\
\hline & $2010-2012$ & 47 & 12 & 46 \\
\hline \multirow{3}{*}{ Прямі виплати фермерам / direct payments } & 1995-1997 & 0 & 21 & 2 \\
\hline & $2005-2007$ & 1 & 28 & 4 \\
\hline & $2010-2012$ & 2 & 20 & 0 \\
\hline
\end{tabular}

Можна помітити, що Індія відсутня у цій таблиці з тієї причини, що ОЕСР не має порівняльних даних по ній. Стосовно прямих виплат фермерам (**), то вони включають виплати з огляду на фактичні показники, що вимагають зустрічних зобов'язань, враховуючи параметри виробництва, а ще з огляду на умовні показники, котрі (не) вимагають зустрічних зобов'язань беручи до уваги параметри виробництва.

На початку 2010-х pp. основу всього обсягу PSE (producer Support Estimate), - від 4/5 у Китаї до майже 100 \% у ПАР, - становили інструменти MPS (Market Price Support) і субсидування споживання вхідних ресурсів. Доводиться констатувати, що продовжують домінувати вкрай руйнівні для ринкових основ господарювання форми підтримки виробника, що пов'язані 3 випуском продукції й використанням факторів виробництва без обмежень за обсягами виготовлення або споживання ресурсів. Лише Китаю вдалося забезпечити підтримку селян за рахунок прямих погектарних / «поголовних» платежів під зустрічні зобов'язання фермерів, «піднявши» їх до 15 \% PSE в середньому за 2010-2012 рр. з нульової позначки ще у 1995-1997 рр. На прикладі структури виплат, пов'язаних з фактичними обсягами виробництва, у всіх країнах домінують інструменти MPS. Чи не вирішальну роль відіграє те, що саме за рахунок MPS у всіх розглянутих країнах коефіцієнт номінального захисту 
Міжнародні відносини: теоретико-практичні аспекти

Випуск 5 (2020)

ISSN (print) 2616-745X; ISSN (online) 2616-7794

агровиробника (NPC) 3 негативного перетворився на позитивним або зміцнився ще більше. Це помітно за наступною таблицею (Agricultural Policy Monitoring and Evaluation, 2013, p. 91, 135, 289, 300, 301, 306, 307):

Таблиця 3

\begin{tabular}{|c|c|c|c|c|c|c|c|c|c|c|}
\hline \multirow[t]{3}{*}{ Країна } & \multicolumn{4}{|c|}{$\begin{array}{c}\text { Оцінка підтримки } \\
\text { агровиробників (PSE) } \\
\text { (\% від усіх } \\
\text { надходжень фермерів } \\
\text { або млн дол.) }\end{array}$} & \multicolumn{4}{|c|}{$\begin{array}{c}\text { Загальна підтримка } \\
\text { сільського } \\
\text { господарства (TSE) } \\
\text { (\% від ВВП) }\end{array}$} & \multicolumn{2}{|c|}{$\begin{array}{c}\text { Номінальний захист } \\
\text { агровиробника } \\
\text { (NPC) }\end{array}$} \\
\hline & \multicolumn{2}{|c|}{$\begin{array}{l}1995- \\
1997\end{array}$} & \multicolumn{2}{|c|}{$\begin{array}{l}2010- \\
2012\end{array}$} & \multicolumn{2}{|c|}{$\begin{array}{c}1995- \\
1997\end{array}$} & \multicolumn{2}{|c|}{$\begin{array}{c}2010- \\
2012\end{array}$} & $\begin{array}{c}1995- \\
1997 \\
\end{array}$ & $\begin{array}{c}2010- \\
2012 \\
\end{array}$ \\
\hline & $\%$ & млн\$ & $\%$ & $\begin{array}{c}\text { млн } \\
\$\end{array}$ & $\%$ & $\begin{array}{c}\text { млн } \\
\$\end{array}$ & $\%$ & млн\$ & коефіцієнт & коефіцієнт \\
\hline $\begin{array}{c}\text { OЕСР } \\
\text { (Срд.) }\end{array}$ & 30,0 & 253,9 & 19 & 252,5 & 1,6 & 344,2 & 0,9 & 402,5 & 1,31 & 1,10 \\
\hline США & 12,0 & 26,6 & 8 & 29,9 & 0,9 & 70,1 & 1,0 & 145,3 & 1,07 & 1,01 \\
\hline$\epsilon C^{*}$ & 34,0 & 116,08 & 19 & 105,3 & 1,5 & 131,8 & 0,7 & 121,4 & 1,33 & 1,04 \\
\hline Бразилія & -12 & $-6,8$ & 5 & 8,7 & 0 & $-3,9$ & 0 & 11,08 & 0,85 & 1,02 \\
\hline Китай & 2 & 5,7 & 15 & 135,3 & 1,4 & 11,5 & 2,3 & $\begin{array}{c}160,0 \\
2\end{array}$ & 1,00 & 1,13 \\
\hline ПАР & 11,0 & 1036 & 3 & 0,499 & 1,0 & 1,5 & 0,2 & 0,8 & 1,13 & 1,01 \\
\hline
\end{tabular}

Примітка. * $Є C-15$ для періоду 1995-2003 рр., $\epsilon C-27$ для періоду з 2007 р.

Якщо вартісні обсяги MPS Бразилії та Китаю не порівнюються, то їхнє змістовне наповнення збігається в головному. Зокрема, щорічно Національна комісія з розвитку й реформ у Китаї в ході консультацій з іншими урядовими структурами затверджує мінімальні ціни на зерно для 13 провінцій з позитивним зерновим балансом, що діють кілька місяців після завершення збирання врожаю. При цьому мінімальні ціни на рис й пшеницю з 2008 р. підвищувалися щорічно незалежно від світової кон'юнктури, що обернулося штучним гальмуванням внутрішніх цін на рис, які істотно програвали світовим, i, навпаки, виведенням внутрішніх цін на пшеницю на рівень вище світового. Однопорядкове призначення - стабілізувати ціни й забезпечити належний рівень поставок продукції на ринок - мають спеціальні / ad hoc інтервенції згідно попередньо зафіксованих цін, зокрема, у 2008-2010 рр., що проводилися відносно цукрового очерету, цукрового буряку, бобових, кукурудзи, ріпаку, бавовни й свинини. До речі, державні інтервенції, покликані стримати 
зростання внутрішніх цін з метою підтримки життєвого рівня незаможного населення, або продиктовані міркуваннями обмеження експорту продовольства, можуть обернутися, а у багатьох випадках якраз і призводять до негативних показників MPS (наприклад, мінус 139,4 млрд юанів у Китаї в 2008 р.) (Agricultural Policy Monitoring and Evaluation, 2011, p. 225, 227).

У Бразилії половина всіх ресурсів, що стабільно скорочуються й направлені на MPS, припадає на Національну програму гарантованих мінімальних цін, призначених, головним чином, для підтримки небагатих сільгоспвиробників у освоюваних районах країни до створення там необхідної інфраструктури. 32010 р. 20 \% коштів, призначені під програму, витрачається на закупівлю продукції сімейних ферм за цінами «вище» ринкових, що не сильно спотворює рух середньо ринкових цін. На політику MPS у Бразилії впливають так звані «вирівнюючі» платежі, які по одній 3 підпрограм виплачуються оптовим покупцям, згодним закуповувати пшеницю і кукурудзу у фермерів за спеціально встановленими мінімальними цінами («вирівнююча» премія як субсидія, що розігрується 3-поміж оптовиків на аукціоні із заздалегідь затвердженою державою межею), за іншою - комерсантам, котрі купують сільськогосподарську продукцію за опціонними контрактами, а згідно третьої підпрограми - безпосередньо фермеру або сільськогосподарському кооперативу в якості різниці між референтною й аукціонною ставками вирівнюючих платежів (Agricultural Policy Monitoring and Evaluation, 2011, p. 216).

Інструментарій MPS, застосований у багатьох прогресуючих країнах, вміщує: адміністрування мінімальних цін для виробників / Minimum Support Prices (MSPs); введення урядами окремих штатів рекомендованих цін / State Advised Prices (SAPs), що перевищують рівень MSP; організацію ринкових інтервенцій / Market Intervention Prices (MIPs); формування буферних запасів зерна / Buffer Stocks Operations (BSOs); підтримку функціоналу системи централізованого забезпечення найбідніших верств продовольством за субсидованими цінами / Indian Targeted Public Distribution System (TPDS); зонування зернового виробництва, що поступово сходить нанівець. Кінцева мета цього інструментарію - підтримка стабільності внутрішніх сільськогосподарських ринків, яка на ділі обертається все більшою ізоляцією останніх від впливу світової кон'юнктури, ускладнює навантаження на бюджет, попутно розганяючи інфляцію.

Імпортні тарифи, тарифні й абсолютні квоти, ліцензування, заохочення або обмеження (відповідно до ситуації на внутрішньому ринку) експорту утворюють другий або «зовнішній» контур інструментів MPS, простір для прояву індивідуального підходу країни, застосування яких регулюється зобов'язаннями перед СОТ. Як правило, середньозважена базова ставка 
імпортного тарифу на сільськогосподарську продукцію для країн з режиму найбільшого сприяння перевищує рівень тарифного захисту непродовольчих товарів: у Китаї - 15,6 \% проти 8,7 \%, в Індії - 33,5 \% на 10,4\%. При цьому, якщо у Китаї сільськогосподарський тариф з середини 2000-х рр. знаходиться на рівні зобов'язань, прийнятих для вступу до СОТ, то Індія з ії середньою ставкою 113,1\%, як i, наприклад, ПАР - фактичні 8,4\% у 2012 р. проти зафіксованої межі 39,6 \%. Практично всі країни на рівні зобов'язань обумовили можливість застосування тарифних квот, наприклад, Китай - на зернові, цукор, шерсть, бавовну й окремі види мінеральних добрив тощо. Разом з тим, Китай домігся дозволу на поділ фізичних обсягів тарифно квотного імпорту між приватним бізнесом і державними торгово-закупівельними організаціями.

Стосовно експортних мит й кількісних обмежень експорту, то СОТ, як відомо, розглядає їх в якості інструментів перешкоджання ринковому зв'язку попиту й пропозиції. Той самий Китай, намагаючись подолати продовольчу інфляцію й стабілізувати постачання зерна на внутрішній ринок, у січні 2008 р. увів тимчасові експортні мита (5-25\%) на 57 товарних позицій зернових й борошномельної продукції, але до червня 2009 р. повністю їх скасував. До того ж китайські експортери дестимулюються державою, яка повертає не базові $13 \%$ «вхідного» ПДВ, а тільки $5 \%$, та й ті зі значними винятками (від 20 грудня 2007 р. китайський уряд взагалі скасував відшкодування ПДВ по 84 товарних позиціях, зокрема пшениці, рису, кукурудзи, бобових і т.п., а від 13 червня 2008 р. - відносно рослинних олій) (Agricultural Policy Monitoring and Evaluation, 2011, p. 231).

Індія лавірує між об'єктивною необхідністю підтримати доходи фермерських господарств, в тому числі, стимулюванням експорту (наприклад, у формі 60 спеціалізованих агроекспортних зон, створених у 20 зі 28 штатів країни для виробництва, переробки й упаковки готової продукції, або надання експортерам фруктів, овочів, квітів, продукції молочної промисловості й птахівництва, звільнення від сплати майбутніх ввізних мит на суму, еквівалентну 5\% вартості експортованої роком раніше сільськогосподарської продукції за цінами FOB) й намаганням забезпечити продовольчу безпеку країни, зокрема, за допомогою мінімізації експортних цін, даючи можливість експортерам експортувати в кращому випадку дорогу високоякісну продукцію, яка не надходить каналами системи TPDS для розподілу серед бідних верств населення (Agricultural Policies in Emerging Economies, 2009, pp. 109-110).

Якщо звернути увагу на платежі за товарне виробництво конкретної продукції, наприклад, в розрахунку за 1 т поставленого на ринок м'яса птиці, за 1 л реалізованого молока / Payments Based on Output (РВО), то можемо бачити, що у Китаї й ПАР на ці цілі з середини 1990-х рр. держава взагалі не виділяє кошти, стосовно Індії достовірна інформація відсутня, а ось 
у Бразилії фінансування хоч й зросло 10-кратно, проте у середньорічному обчисленні за 2010-2012 pp. 5 \% PSE.

I ще одним руйнівним елементом PSE для ринкового середовища функціонування сільського господарства вважається субсидування «вхідних» витрат від 12 \% PSE у Китаї до 47 \% в Бразилії. По Індії OECP PSE не вираховує. Цей вид державної підтримки агропродовольчого комплексу згідно методології ОЕСР зводиться до трьох основних різновидів трансферів: 1) зниження прямих виробничих витрат споживання виробником конкретного виду «вхідних» ресурсів або їх поєднання; 2) скорочення витрат фермерів на будівництво будівель й споруд, придбання сільськогосподарських машин та устаткування, проведення меліоративних робіт й захист грунтів; 3) покриття частини витрат 3 надання фермерським господарствам технічного, санітарного, фітосанітарного, загально комерційного сприяння й професійної перепідготовки. Щоб було зрозуміло, на рівні країни йдеться про прямі бюджетні субсидії (трансферти або не стягнення з фермерів належних державі частини платежів), що мають свою змістовну специфіку.

Аналізуючи ситуацію серед обраних країн, можна помітити, що лише Китаю вдається послідовно рік за роком скорочувати обсяги деструктивного субсидування «вхідних» виробничих витрат сільського господарства, паралельно переводячи ресурси вивільнені ресурси до складу менш руйнівних. За реалізацію відповідних програм, починаючи з податкової реформи 1994 р., поряд з центральним урядом відповідають уряди провінцій, котрі зобов'язані співфінансувати бюджетні трансферти, направлені Пекіном на сільське господарство. 3-поміж найбільш важливих рішень у цьому напрямку виділимо впровадження у 2006 р. так званої комплексної субсидії, початковою метою якої оголошувалася компенсація виробникам зерна підняття цін на мінеральні добрива, пестициди й дизпаливо, але яка по факту перетворилася на погектарні платежі й вид прямих виплат, покликаних підтримати фермерські прибутки, ставши найбільшим бюджетним трансфертом у цій країні до початку 2010-х рр.

У якості елемента «вхідного» субсидування агровиробництва у Китаї можна також розглядати застосування преференційних цін на електроенергію й природний газ, які споживаються заводами-виробниками, пільгових тарифів на транспортування мінеральних добрив країною, звільнення продуцентів від сплати внесків до фонду залізничного будівництва й ПДВ. Втім, саме ці бюджетні витрати за 2007-2010 pp. державі вдалося скоротити вдвічі до 5,3 млрд дол., «перекинувши» зекономлені кошти на потроєння субсидування за той же період. Нарешті, не можна не відзначити запуск урядом Китаю у 2007 р. пілотного проекту субсидування страхування одночасно рослинництва й тваринництва, відповідно до якого тягар сплати страхової премії страховику ділиться «між трьома»: центральним, місцевим урядами, й 
безпосередньо фермером, а внесок «центру» збільшується з 35 \% до 40 \% (1,5 млрд дол. У 2010 р.), за умови збереження незмінної частки провінцій на рівні $1 / 3$ й скорочення фермерських видатків (Agricultural Policy Monitoring and Evaluation, 2011, pp. 229-230).

Ця нова форма державної підтримки поступово набуває поширення й в інших країнах, приміром, у Бразилії, де витрати федерального уряду на субсидування страхування агровиробництва, лісівництва й аквакультури поки на порядок менше, ніж у Китаї (125 млн дол. у 2010 р.), але «зона охоплення» страхуванням стрімко розширюється: від 1,6 млн га у 2006 р. до 7,7 млн га у 2010 p. (Agricultural Policy Monitoring and Evaluation, 2011, p. 218). Бразилія, як і ПАР, відноситься до групи країн 3 помірним обсягом «вхідного» субсидування (46-47 \% PSE на кожен окремий випадок). У ПАР через скромні параметри сприяння практично все зводиться до відшкодування всіх податків й дорожніх зборів, яке закладене в ціну дизпалива, використаного під час виробництва сільськогосподарської сировини, та практикується з 2000 p. У розрахунку на 1 л солярки рівень компенсації зріс від 0,84 ранда у $2007 \mathrm{p}$. до 1,58 ранда (близько $12 \%$ оптової ціни) у 2012 p. (Agricultural Policy Monitoring and Evaluation, 2013, p. 253). Єдине обмеження - відшкодовується не більше 80 \% витраченого фермером дизпалива у первинному виробництві. Відносно бразильської специфіки, то вона полягає у $70 \%$ виділених на розглянуті цілі ресурсів, що витрачаються на субсидування інвестиційних кредитів. В залежності від певної категорії ( «А» - переселенці на землях, що потребують освоєння, «В»- 1,8 млн дрібних господарств, прибуток яких за попередній рік менше 3,4 тис. дол., «С»- 2,4 млн сімейних ферм 3 річним доходом від 3,4 до 62 тис. дол.) кожне фермерське господарство у Бразилії може розраховувати на отримання інвесткредиту до 76,3 тис. дол. й кредиту на поповнення обігових коштів до 28 тис.дол. у розрахунку на окрему оброблювану культуру (сумарно - до 130 тис. дол.) на пільгових умовах в середньому під 2,5\% річних (Agricultural Policy Monitoring and Evaluation, 2011, p. 217-218). При цьому, абсолютні параметри процентного субсидування держава намагається стримувати, а саме, сукупний обсяг продуктової підтримки сільського господарства ніколи не перевищував $1 \%$ вартості виробленої валової сільськогосподарської продукції (Brink, Orden, Datz, 2013, p. 204).

Ну й те, що стосується прямих виплат фермерам / Direct Payments (DPs), то ОЕСР визнає їх менш руйнівними у ринкових умовах господарювання та заохочує перехід інструментарію MPS i «вхідного» субсидування на ці засади. На початку 2010-х pp. DPs у структурі PSE прогресуючих країн займали більш ніж скромне місце: фактично обнулені у ПАР, практично непомітні (2 \% PSE) у Бразилії, і лише Китаю вдалося розгорнути головний напрямок аграрної 
політики, по суті 3 нуля у середині 1990-хрр. до 1/5 PSE. Структурну різноманітність прямих платежів, спрямованих на зміцнення доходів фермерських господарств, можна розглянути як раз на прикладі Китаю. $80 \%$ всього обсягу DPs в середньому за 2010-2012 рр. припадали на трансферти платників податків сільгоспвиробникам, пов'язаних з розмірами площ / поголів'я худоби / виручки / прибутку, головним чином, у формі «погектарних» виплат, до яких Китай звернувся у 2004 р. Спочатку Національний зерновий страховий фонд затвердив фіксовані «поземельні» платежі (10-15 юанів в розрахунку на 1 або 1/15 га, тобто 22-23 дол. на 1 га, залежно від площ, засіяних рисом, пшеницею чи кукурудзою) для 13 головних зерносіючих провінцій. Однак остаточне вирішення питання про визначення «основного ареалу обробітку» залишалося за владою регіонів. Надалі держава збільшувала як набір субсидованих у такий спосіб культур (поступово включивши бавовну, рис, сою-боби, картоплю, ячмінь, арахіс), так і частку площ під засіви (з 2008 р субсидуванням охоплені всі посіви рису, з 2009 р. - пшениці, бавовни і - у чотирьох провінціях - ріпаку), одночасно корегуючи механізм субсидування.

\section{Висновки}

Підводячи підсумки вищевикладеного й, відштовхуючись від проаналізованого, виділимо три принципові особливості «вбудовування» аграрного сектора розглянутих країн у систему міжнародного поділу праці в умовах глобалізації. По-перше, порівняльний аналіз умов вступу до СОТ дозволив виявити загальні напрямки коригування державної аграрної політики Бразилії, Індії, Китаю та ПАР: збереження, в головному, рівня тарифного, а десь й нетарифного захисту (використання тарифних квот) з послідовним перекладом останнього (ветеринарний, санітарний контроль, ін.) на єдині стандарти; поступовий перехід до найменш деструктивних відносно ринку форм підтримки агровиробників; підтягування до середніх питомих показниками рівнів PSE і TSE у країнах OECР. По-друге, вступ до COT і прийняття фіксованих зобов'язань не сповільнили розвиток аграрного сектора зазначених країн, що підтверджується динамікою валового сільськогосподарського виробництва, яка різко прискорилася якраз на етапі 2000-х рр. й випередила темпи зростання населення; зростанням рівня продуктивності сільського господарства (до прикладу, врожайність цукрового очерету Бразилії у 1995-1997 pр. на 5,9 \% перевершувала середньосвітовий рівень, а у 2009-2011 рр. - вже на 10,7 \%, тоді як Китай зберігає свою більш ніж 1,5-кратну перевагу за врожайністю рису над середнім по світу показником, а у випадку з врожаєм пшениці ПАР скорочує відставання за рахунок оформлення потужного агроекспортного сектору економіки). По-третє, членство у СОТ не перешкоджає пошуку індивідуальних, «заточених» під 
конкретику певного періоду в окремій країні форм підтримки сільського господарства, природно стимулюючи їхнє наближення спочатку до рівня бажаних прямих платежів, що підвищують доходи фермерів, а згодом до зеленої корзини, залишаючи простір для «виторговування» сприятливих умов державної підтримки розвитку сільського господарства в рамках Дохійського раунду переговорів.

\section{References:}

1. Agricultural Policies in Emerging Economies. (2009). Monitoring and Evaluation. OECD Publishing.

2. Agricultural Policy Monitoring and Evaluation. (2011). OECD Countries and Emerging Economies. OECD Publishing.

3. Agricultural Policies Monitoring and Evaluation. (2012). OECD Countries and Emerging Economies. OECD Publishing.

4. Agricultural Policy Monitoring and Evaluation. (2013). OECD Countries and Emerging Economies. OECD Publishing.

5. Agricultural Policy in South Africa: A Discussion Document. Box 2. Available at: http://www.nda.agric.za/docs/Policy/policy98.htm.

6. Agriculture, Trade and Food Security Issues and Options in the WTO Negotiations from the Perspective of Developing Countries. FAO 2000, Vol. II, Chapter 6. Available at: http://www.fao.org/docrep/005/y4632e/y4632e0g.htm.

7. Anderson, K. (2010). Globalization's Effects on World Agricultural Trade, 1960-2050. Philosophical Transactions of The Royal Society (Biological Science), Vol. 365, no. 1554, pp. 3008-3009.

8. Brink, L., Orden, D. and Datz G. (2013). BRIC Agricultural Policies Through a WTO Lens. Journal of Agricultural Economics, Vol. 64, no. 1, pp. 197-216.

9. Dhar, B. (2004). Agriculture and the WTO: An Indian Perspective. Available at:http://wbwto.iift.ac.in/Downloads/WSII/WT0\%20and\%20Indian\%20Agriculture. pdf.

10. Domestic Support and WTO Obligations in Key Developing Countries. (2011). DTB Associates, LLP. September.

11. FAOStat, [online]. Available at: http://faostat.fao.org

12. Federico, F. (2005). Feeding the World: an economic history of agriculture 1800-2000. Princeton University Press.

13. Greenberg, S. (2010). Status Report on Land and Agricultural Policy in South Africa. PLAAS Studies Research Report 40. University of the Western Cape, Institute for Poverty, Land and Agrarian Studies.

14. Hanrahan, C.E. (2013). Agricultural Export Programs: Background and Issues. CRS Report for Congress. June 18, pp. 12-13. 
15. Huang, J. and Rozelle, S. (2002). China's Accession to WTO and Shifts in the Agriculture Policy. Working Paper, no. 02-002. University of California Davis, January, pp. 11-15.

16. Market Access: Unfinished Business. WTO Special Studies 6, P. 75. Available at: http://www.wto.org/english/res_e/booksp_e/maccess_e.pdf.

17. OECD Statistics. Available at: http://stats.oecd.org/

18. Orden, D., Blandford, D., Josling, T. (2011). WTO Disciplines on Agricultural Support: Seeking a Fair Basis for Trade. Cambridge University Press.

19. WTO Statistics Database, [online]. Available at: http://stat.wto.org/.

20. World Bank Indicators, [online]. Available at: http://data.worldbank.org/indicator.

(C) Ревенко А. Д., 2020 